\title{
Microbiological Aspects of the Submerged-Culture Production of Penicillin on a Pilot-Plant Scale
}

\author{
By E. GRENFELL, B. J. LEGGE ANd T. WHITE \\ The Research Laboratories, John Wyeth and Bro. Ltd., London
}

\begin{abstract}
SUMMARY: The use of mechanical air filtration combined with ultra-violet irradiation of the filtered air has aided markedly in avoiding contamination by undesirable micro-organisms during pilot-plant scale work on penicillin production. By maintaining master cultures of Penicillium strains in sterile soil it has been found possible to eliminate strain variation and to maintain the penicillin-producing eapacity of the strains. This procedure, followed by transfer of the organism to a rye grain substrate, gives a convenient method of securing large numbers of spores for large-scale work.

It has been found to be desirable to check the purity of the strains, their penicillinproducing capacity and the viability of the spores at various stages of the production sequence; methods have been developed for each of these requirements. Improvements in the cup assay method of estimating penicillin have eliminated certain difficulties encountered in this assay and have enabled the overall error of the method to be reduced to $5 \%$. A colorimetric method of assay has been developed which gives results agreeing with those of the cup assay. With this new method the penicillin content of a sample can be estimated in $5 \mathrm{hr}$.
\end{abstract}

Earlier work on penicillin formation showed that this is a particularly intricate microbiological process (Fleming, 1929; Clutterbuck, Lovell \& Raistrick, 1932; Abraham, Chain, Fletcher, Gardner, Heatley, Jennings \& Florey, 1941). The progress made towards a solution of this problem has remained secret (under wartime regulations) until recently, when groups of workers in the U.S.A. published certain information regarding techniques used in the study of the surface and submerged culture formation of penicillin. These papers, which will be referred to in detail later, do not discuss many aspects of practical importance, and the present communication gives some account of methods used in these laboratories to secure adequate yields of penicillin in submerged culture of the mould on a pilot-plant scale.

The most important practical microbiological problems involved are: (a) selecting and maintaining Penicillium strains of good penicillin-producing capacity; $(b)$ obtaining the bulk of spores required as inoculum for large-scale operations; $(c)$ eliminating contamination with other micro-organisms at all stages; $(d)$ carrying out the process of penicillin formation under controlled conditions; $(e)$ following the course of penicillin formation accurately.

Abraham et al. (1941) gave information of practical value on these points for surface culture, but the first detailed statement of basic principles for larger scale operation was that of Foster, Woodruff \& McDaniel (1943). These authors showed that, in order to obtain reasonable yields of penicillin, it was necessary to select strains and to avoid the degeneration of penicillin-producing 
capacity which is so marked in Penicillium spp. They stated that such degeneration was best eliminated by carrying master strains in lyophilized soil culture to avoid successive transfers on artificial media, and indicated the importance of using multiple-spore inocula instead of the more normal practice of attempting to establish pure lines by single-spore isolation. Stress was also laid on the value of proceeding from the master-soil cultures to the production stage with the minimum number of intermediate transfers. These points were emphasized by Moyer \& Coghill (1946 $a$ ), who advocated the preservation of cultures by the lyophile method (see Thọm \& Raper, 1945).

The value of strain selection was discussed in more detail by Raper, Alexander \& Coghill (1944), who first described the 'screening test' for assessing the potential value of strains. Agar plugs taken from the surrounds of $\boldsymbol{P}$. notatum colonies grown on modified Czapek's agar were implanted on plates seeded with Staphylococcus aureus and the strain value assessed by observing the size of the inhibition zone produced by diffusion of penicillin from each plug. The method had quantitative limitations, but was of great value in eliminating poor strains and was used in the recent isolation of highpotency mutants after irradiation treatment (Raper \& Fennell, 1946; Hanson, Myers, Stahly \& Birkeland, 1946).

The technique of obtaining large quantities of spores was developed largely by workers at the Northern Regional Research Laboratories, Peoria, and was eventually described by Moyer \& Coghill (1946 $a$ ). They used a 'liquid sporulation medium ' which stimulated heavy sporing of Penicillium strains, and also described the method in which the organism was inoculated into sterile wholemeal bread or (Moyer \& Coghill, $1946 b)$ wheat bran moistened with $2 \%(\mathrm{v} / \mathrm{v})$ corn-steep liquor solution. The particular application of these methods to the preparation of inocula for deep-culture fermentation has been described by Koffler, Emerson, Perlman \& Burris (1945) and by Moyer \& Coghill (1946 b); these papers also deal briefly with the use of germinated spore suspensions for the inoculation of shake flask, aerated bottle, and aerated tank fermentations. In these laboratories we had been fortunate in having the guidance of G. R. Rettew (private communications) of our associate U.S. company, and acknowledgement should be made of his unpublished work on many of the above problems. In particular, he had used the soil technique for maintaining mycological cultures of commercial importance long before penicillin production was contemplated, and had developed, too, the system of intermediate transfer of master strains to sterile rye grain for obtaining high yields of spores. His advice on sterilization by physical methods was also invaluable.

The problem of avoiding contamination by other micro-organisms during large-scale operations with Penicillium has received no attention in the literature, although it was, perhaps, the major problem in such work. Outside the penicillin field, methods of eliminating air-borne and other undesirable micro-organisms have been described by Rahn (1945) and Reyniers (1943). In our work we have used in particular ultra-violet (U.v.) irradiation and mechanical filtration.

The assay of penicillin by the cup method was developed originally by 
Abraham et al. (1941), and improved by Foster \& Woodruff $(1943,1944)$; it has also been discussed by Schmidt \& Moyer (1944), Beadle, Mitchell \& Bonner (1945) and by Knudsen \& Randall (1945). Despite the care with which these workers described the method they left unmentioned factors which can cause appreciable variation of results, and we found it necessary to investigate the method further and to develop an alternative more rapid method of assay which would give results in agreement with those of the cup assay.

Our methods have been based partly on the above published work, partly on data made available by the penicillin information exchange scheme, and partly on our own investigations. The following details may be of value to workers in this and related fields who, by virtue of the war, have not had access to information which is of some importance. The value of these techniques may be judged from the results described by Gordon, Grenfell, Knowles, Legge, McAllister \& White (1947), and by the fact that they were achieved without contamination difficulties in laboratories in which similar large-scale work with a Bacillus capable of destroying penicillin was also in progress.

\section{EXPERIMENTAL}

\section{Culture media}

(1) Nutrient agar. Difco peptone, 5 g.; Difco yeast extract, 3 g.; Difco beef extract, $1.5 \mathrm{~g}$. ; glucose, $1 \mathrm{~g}$.; 'Davis' agar, $10 \mathrm{~g}$.; distilled water to 1 1.; $\mathrm{pH}$ adjusted to $7 \cdot 2$ before sterilizing $(6 \cdot 9-7 \cdot 0$ in final medium). After pouring, plates were incubated at $37^{\circ}$ to test sterility.

(2) Modified Czapek's agar. $\mathrm{NaNO}_{3}, 3$ g.; $\mathrm{KH}_{2} \mathrm{PO}_{4}, 1$ g.; $\mathrm{MgSO}_{4}, 7 \mathrm{H}_{2} \mathrm{O}, 0.5$ g.; $\mathrm{KCl}, 0.5$ g.; $\mathrm{FeSO}_{4}, 7 \mathrm{H}_{2} \mathrm{O}, 0.01$ g.; sucrose (brown sugar), 30 g.; 'Davis' agar, 15 g.; corn-steep liquor, $10 \mathrm{ml}$; distilled water to 11 .; $\mathrm{pH}$ adjusted to 5.6 before sterilization (5.3-5.9 in final medium). After pouring, plates were incubated at $25^{\circ}$ to test sterility.

(3) 'Sporulation' agar (Moyer slope). This medium was introduced by Moyer (unpublished work) and is similar to that of Moyer \& Coghill (1946 $a$ ). The composition is as follows: $\mathrm{NaCl}, 40 \mathrm{~g}$.; $\mathrm{KCl}, 0.2 \mathrm{~g}$.; $\mathrm{KH}_{2} \mathrm{PO}_{4}, 0.06 \mathrm{~g}$.; $\mathrm{MgSO}_{4}, 7 \mathrm{H}_{2} \mathrm{O}, 0.05 \mathrm{~g}$.; $\mathrm{ZnSO}_{4}, 7 \mathrm{H}_{2} \mathrm{O}, 0.022 \mathrm{~g}$. ; $\mathrm{FeSO}_{4}, \mathrm{7H}_{2} \mathrm{O}, 0 \cdot 005 \mathrm{~g}$.; brown sugar, $40 \mathrm{~g}$.; 'Davis' agar, $30 \mathrm{~g}$.; molasses, $4 \mathrm{ml}$; ; corn-steep liquor, $4 \mathrm{ml}$; d distilled water to $1 \mathrm{l}$.; $\mathrm{pH} \mathrm{4.3-5 \cdot 0}$ in final medium without adjustment. The agar is omitted if a liquid medium is required.

(4) Nutrient broth. Cultures of Staph. aureus used as inocula for penicillin assays were grown on this medium, the composition of which was: Difco peptone, $5 \mathrm{~g}$.; Difco yeast extract, 1.5 g.; Difco beef extract, 1.5 g.; glucose, 1 g.; phosphate buffer $\mathrm{pH} 7 \cdot 0\left(8.4 \mathrm{~g}\right.$. $\mathrm{K}_{2} \mathrm{HPO}_{4}+3 \cdot 0 \mathrm{~g}$. $\left.\mathrm{KH}_{2} \mathrm{PO}_{4} /.\right)$, $500 \mathrm{ml}$.; distilled water to $1 \mathrm{l}$.; pH 7.0 without adjustment.

\section{The 'sterile room'}

Transfers of Penicillium were carried out in an adapted part of the laboratory termed, for convenience, the 'sterile room'. Its use was essential for the inoculation technique described later, since contamination by penicillindestroying organisms would have been inevitable if transfers had been made in the normal laboratory atmosphere. The arrangement of the sterile room is shown in Fig. 1. 
An air filter (constructed to design by Airscrew, Ltd., Weybridge, Surrey) set in the inner wall drew air from an outer air-lock through a felt bacterial filter into the inner (inoculating) portion of the room, giving twelve air changes an hour in this area. A strip U.v. lamp ('Hanovia') on the wall opposite the air intake was directed horizontally so that any organisms passing the filter were immediately exposed to U.v. irradiation, which was most intense in the upper third of the inoculating room. The filtered, irradiated air then swept down and out through a grill in the bottom of the inoculating room door into the air-lock. Here it was drawn again to the filter past a second U.v. lamp (directed downwards) above the sterile gowns referred to later. The air in the sterile room was thus continuously circulated, filtered, and irradiatedthe inoculating room proper being always under a slight positive pressure. The airlock contained three previously sterilized gowns and masks hung immediately below the U.v. lamp; these were replaced after using three or four times, or after known contamination. The inner room contained only a stool, enamelled-top table and gas burner.

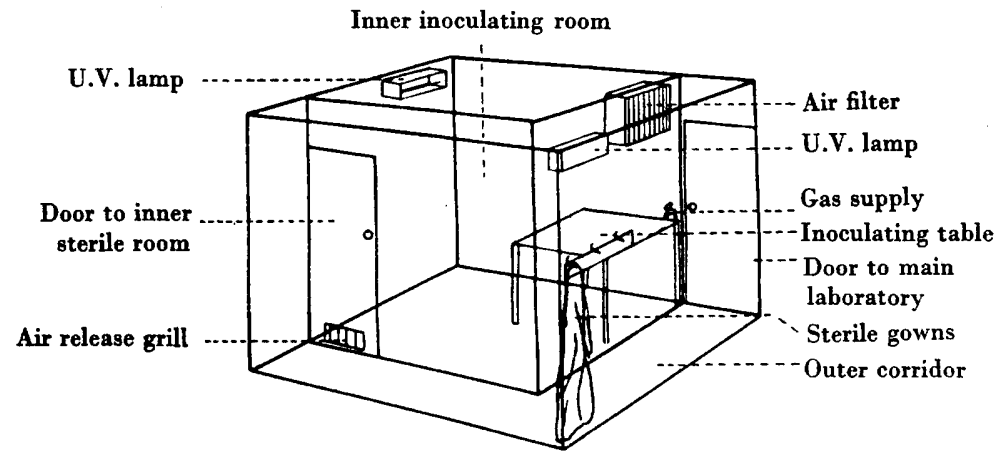

Fig. 1. The 'sterile room'.

The following procedure was adopted in using the sterile room. Cultures and apparatus were placed on a surgical trolley together with thin surgical rubber gloves, $0 \cdot 1 \%(w / v)$ mercuric bichloride solution, absorbent cotton-wool swabs and a spray gun. Two operators entered the air-lock with this trolley, donned the inoculating gowns, masks and gloves, and swabbed the latter with bichloride solution. The trolley, and the surfaces of culture containers and apparatus on the trolley, were then swabbed with bichloride by one operator, while the other sprayed the air-lock and then the inoculating room with calcium hypochlorite solution $(0.06 \%$ available chlorine). Both operators then entered the inoculating room with the trolley, and reswabbed the gloves, culture containers and apparatus before placing the latter on the swabbed inoculating table. Cotton-wool plugs were then pulled out slightly, flamed, and pushed back into position with a damp swab. Transfers were effected as in normal mycological routine. Pouring, when necessary, was done through a flame unless living organisms were present in the liquid, when it was performed immediately under a flame. The table top was reswabbed and the inoculating room and air-lock resprayed after use.

The efficiency of the arrangement in producing aseptic conditions was tested as follows, three experiments being conducted in each case. The sterile room was first deliberately contaminated by operators in non-sterile clothing, the filter and U.v. lamps having been switched off and the doors opened to the main laboratory atmosphere for an hour.

Two plates each of nutrient agar and modified Czapek's agar were exposed 
for one hour on the inoculating table, on the window sill of the air-lock and on a central shelf in the main laboratory. The doors of the inoculating room and the air-lock were closed, the filter operated for $24 \mathrm{hr}$., and a second set of plates then exposed for $1 \mathrm{hr}$. In one of the three experiments the U.v. lamps were put into operation over a second $24 \mathrm{hr}$. period and a third set of plates exposed. The room was then sprayed with hypochlorite solution and a fourth set of plates exposed immediately. The Czapek agar plates were incubated at $25^{\circ}$ for 3 days, and the nutrient agar plates at $37^{\circ}$ for 1 day and then at $25^{\circ}$ for 2 days. Mould colonies on the former, and bacterial and yeast

Table'1. Experimental test of the 'sterile room'

Treatment

\begin{tabular}{|c|c|c|c|c|c|c|c|c|c|c|c|c|c|}
\hline \multirow[b]{2}{*}{$\begin{array}{l}\text { Exp. } \\
\text { no. }\end{array}$} & \multirow[b]{2}{*}{ Place } & \multicolumn{3}{|c|}{ None } & \multicolumn{3}{|c|}{ Filter* (1 day) } & \multicolumn{3}{|c|}{$\begin{array}{c}\text { Filter (2 days) } \\
\text { v.v. } \dagger \text { (1 day) }\end{array}$} & \multicolumn{3}{|c|}{$\begin{array}{c}\text { Filter (2 days) } \\
\text { U.v. (1 day), } \\
\text { spray } \ddagger\end{array}$} \\
\hline & & $\begin{array}{l}\text { Bac- } \\
\text { teria }\end{array}$ & Moulds & Both & $\begin{array}{l}\text { Bac- } \\
\text { teria }\end{array}$ & Moulds & Both & $\begin{array}{l}\text { Bac- } \\
\text { teria }\end{array}$ & Moulds & Both & $\begin{array}{l}\text { Bac- } \\
\text { teria }\end{array}$ & Moulds & Both \\
\hline 1 & $\begin{array}{l}\mathbf{A} \\
\mathbf{B} \\
\mathbf{C}\end{array}$ & $\begin{array}{r}111 \\
20 \\
26\end{array}$ & $\begin{array}{l}44 \\
17 \\
27\end{array}$ & $\begin{array}{r}155 \\
37 \\
53\end{array}$ & $\begin{array}{r}114 \\
6 \\
2\end{array}$ & $\begin{array}{l}8 \\
4 \\
1\end{array}$ & $\begin{array}{r}122 \\
10 \\
3\end{array}$ & - & - & - & - & - & - \\
\hline 2 & $\begin{array}{l}\mathbf{A} \\
\mathbf{B} \\
\mathbf{C}\end{array}$ & $\begin{array}{r}\mathbf{3 5 0} \\
\mathbf{5 0} \\
\mathbf{3 4}\end{array}$ & $\begin{array}{r}12 \\
2 \\
5\end{array}$ & $\begin{array}{r}362 \\
52 \\
39\end{array}$ & $\begin{array}{r}278 \\
16 \\
4\end{array}$ & $\begin{array}{r}36 \\
10 \\
0\end{array}$ & $\begin{array}{r}314 \\
26 \\
4\end{array}$ & - & - & - & - & - & - \\
\hline $\mathbf{3}$ & $\begin{array}{l}\mathbf{A} \\
\mathbf{B} \\
\mathbf{C}\end{array}$ & $\begin{array}{r}494 \\
117 \\
96\end{array}$ & $\begin{array}{r}14 \\
6 \\
3\end{array}$ & $\begin{array}{r}508 \\
123 \\
99\end{array}$ & $\begin{array}{r}891 \\
41 \\
22\end{array}$ & $\begin{array}{r}31 \\
3 \\
1\end{array}$ & $\begin{array}{r}922 \\
44 \\
23\end{array}$ & $\begin{array}{r}192 \\
6 \\
2\end{array}$ & $\begin{array}{r}15 \\
5 \\
1\end{array}$ & $\begin{array}{r}207 \\
11 \\
3\end{array}$ & $\begin{array}{r}314 \\
14 \\
5\end{array}$ & $\begin{array}{r}20 \\
4 \\
1\end{array}$ & $\begin{array}{r}334 \\
18 \\
6\end{array}$ \\
\hline
\end{tabular}

$A$, outer laboratory; $B$, air-lock of sterile room; $C$, inner portion of sterile room.

The figures represent the average colony count from duplicate plates exposed for $1 \mathrm{hr}$. in the places indicated; surface area of plate $=c .30 \mathrm{~cm} .{ }^{2}$.

* Air filtration system turned on. † Ultra-violet lamps turned on. $\ddagger$ Room sprayed with hypochlorite solution.

colonies on the latter were then counted, and the results for duplicate plates averaged. Table 1 gives the results of these experiments. The contamination of the main laboratory was investigated nine times, giving an average of 336 micro-organisms per plate per hr. (308 bacteria and yeasts plus 28 moulds). More than $90 \%$ of the bacterial colonies were Bacillus brevis, no doubt as a result of contemporary work with this organism. The degree of contamination of the air-lock and of the inner portion of the sterile room was always decreased to 5-8 and 1-2\% respectively of that of the main laboratory at the same time. Since these percentages were obtained after all types of treatment, it was presumed that entry and exit of the operators involved these amounts of contamination, and it was concluded that the filter was efficient in removing micro-organisms from the air circulating in the inoculating room.

In view of the heavy unavoidable contamination of the main laboratories due to pilot-scale antibiotic extraction work, the efficiency of the system is clearly high and its value is shown by the fact that contamination never became a problem throughout the work. 


\section{Maintenance and storage of stock cultures}

It has already been pointed out that maintenance of the penicillin-producing capacity of Penicillium strains is a serious problem. In our work, new strains were subcultured immediately on receipt to provide stock cultures for storage, and to obviate the necessity of opening the original culture too often. If the new strain was received as a soil-spore culture, it was subcultured on a slope of sporulation agar and incubated for 5 days at $25^{\circ}$. Sterile distilled water $(5 \mathrm{ml}$.) was added to this slope culture (or to that of a new strain received in this form) and $1 \mathrm{ml}$. quantities of the resultant spore suspension transferred to stock soil tubes. These were prepared by the method of Thom \& Raper (1945) by autoclaving $3 \mathrm{~g}$. lots of moistened soil at $15 \mathrm{lb}$. pressure for $20 \mathrm{~min}$. on three successive days. The inoculated soil tubes served as master cultures for the strain and were stored at $4^{\circ}$ where they dried out gradually. This process had no adverse effects on Penicillium or Aspergillus spp., although it was fatal in the case of a Fusarium and should not be considered applicable to all fungi. The master soil suspensions were normally used to initiate the first production sequence of the strain (see Chart in the next section), and were then stored for reference. Further sequences were carried out with the second (storage) soil suspension described later. If these gave poorer results than those given by the master soil stock, they were discarded and the latter used again. The technique is safer than continuous transfer on agar, is simpler than the lyophile method of storage, and gave satisfactory maintenance of strain quality.

\section{Stages leading to penicillin production}

For the reasons given earlier it was considered necessary to have as few transfers as possible between strain storage and production, or between successive stages of storage. The following chart shows the procedure adopted to obtain a growing and sporulating culture, and to allow of a purity test, a potency test, continuation of storage, and of a large supply of spores for germination and subsequent inoculation of production media.

A loop of soil plus spores was transferred from the master stock culture to a Moyer's agar slope and incubated at $25^{\circ}$ for 5 days. Distilled water $(5 \mathrm{ml}$.) was then added and the tube agitated to release the spores. The spore suspension so obtained was used to inoculate one $20 \mathrm{oz}$. Roux bottle, three plates of modified Czapek's agar, and two rye grain flasks (vide infra). It could also be used to prepare further soil suspensions for storage but we have preferred the alternative method shown.

\section{Roux bottle culture and strain purity}

The Roux bottle culture was intended to test the purity of the strain and contained $100 \mathrm{ml}$. modified Czapek's agar (composition as given earlier except that $\mathrm{K}_{2} \mathrm{HPO}_{4}$ was used instead of $\mathrm{KH}_{2} \mathrm{PO}_{4}$, and the $\mathrm{pH}$ was 7.2). A loop of spore suspension was spread over the agar surface, larger quantities having 
proved unsatisfactory as the liquid was absorbed unevenly with consequent effect upon the colonial appearance. After incubation at $25^{\circ}$ for 5 days the colonies were examined macroscopically for such morphological dissimilarity as inhomogeneity or sectoring. Changes of this kind usually denoted impurity, or mutation with alteration of the antibiotic properties, and such cultures were stored until subcultures had been taken and tested further.

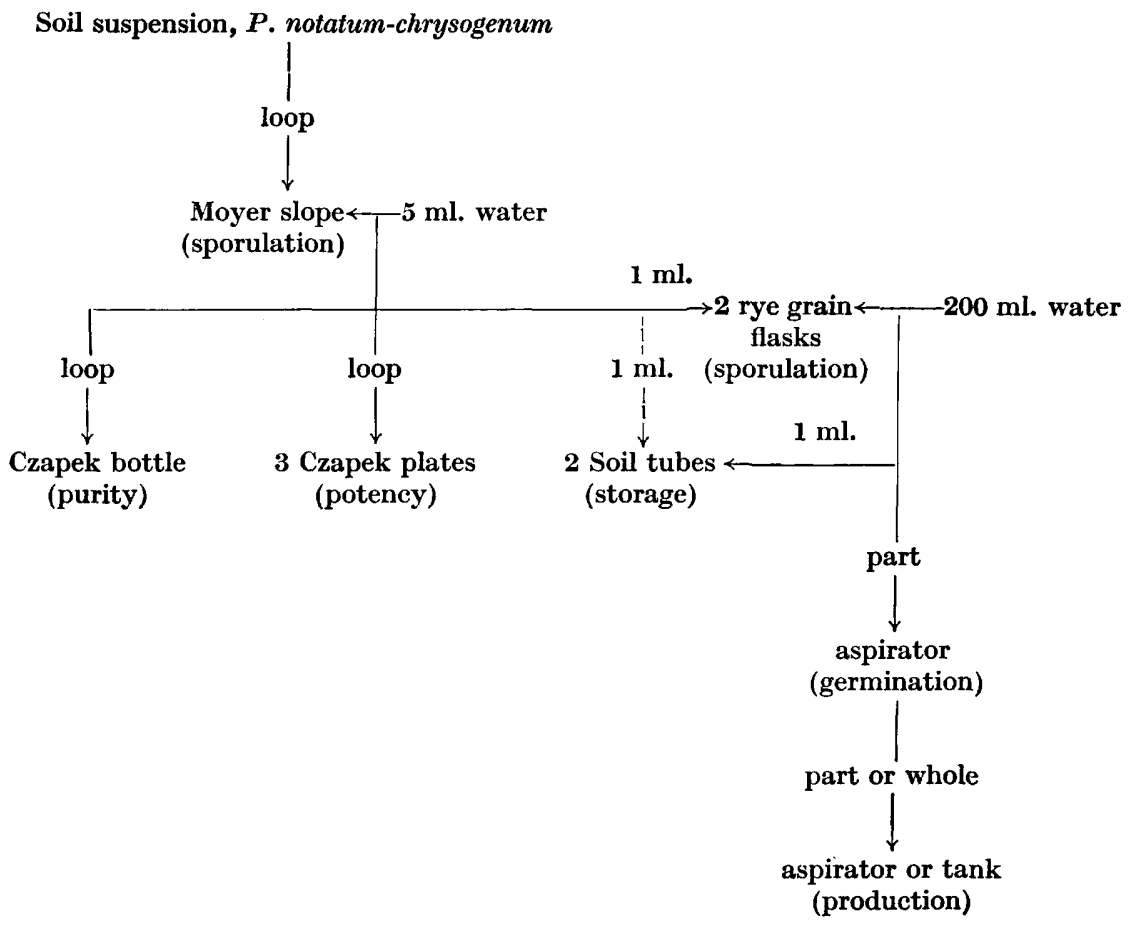

Chart of stages in the submerged-culture production of penicillin

A typical example of the importance of this purity test is seen in the case of a strain of $\boldsymbol{P}$. chrysogenum $\mathrm{X} 1612$ which was received as a soil culture from the U.S.A. and gave satisfactory results for some 4 months. A few differently coloured colonies then appeared in a Roux bottle culture and regularly thereafter, the capacity of the strain for producing penicillin in submerged culture diminishing progressively at the same time. Subcultures taken from atypical colonies or colony sectors were tested for capacity to produce penicillin by the plug assay method described later; they were also examined under the microscope. The two most common types of colony were developed through the production stages and grown in submerged culture in aspirator bottles. Subsequent transfers showed the mutant colonies to be stable. The results of these investigations are summarized in Table 2. Plug assay results with the light and dark green colonies were not significantly different and gave no indication of the greater capacity of the latter for producing penicillin in submerged culture, the assay method being qualitative rather than quanti- 
tative. On the other hand, the much poorer cream mutant would normally be eliminated by this technique. Microscopic examination revealed no significant difference between the light and dark green colonies, but confirmed the suspected absence of sporulation in the case of the cream colonies. It is clear from this example that routine testing of strains for purity is essential if desirable properties are to be maintained. No conclusions were reached as to the reasons for the deterioration of this particular strain.

Table 2. Deterioration of a strain of $\mathrm{P}$. chrysogenum $\mathrm{X} 1612$

\begin{tabular}{|c|c|c|c|c|c|c|}
\hline $\begin{array}{l}\text { Origin of } \\
\text { variant }\end{array}$ & $\begin{array}{l}\text { Incidence } \\
(\%)\end{array}$ & $\begin{array}{c}\text { Colonial } \\
\text { appearance }\end{array}$ & $\begin{array}{l}\text { No. of } \\
\text { colonies } \\
\text { tested }\end{array}$ & $\begin{array}{l}\text { Average } \\
\text { diameter } \\
\text { of } \\
\text { colonies } \\
\text { (mm.) }\end{array}$ & $\begin{array}{c}\text { Average } \\
\text { diameter } \\
\text { of inhibi- } \\
\text { tion } \\
\text { zone* } \\
(\mathrm{mm} .)\end{array}$ & $\begin{array}{l}\text { Penicillin } \\
\text { yield in } \\
\text { aspirator } \\
\text { deep } \\
\text { culture } \\
\text { (Oxford } \\
\text { units/ml.) }\end{array}$ \\
\hline $\begin{array}{l}\text { Strain before colony } \\
\text { variation }\end{array}$ & 100 & $\begin{array}{c}\text { Light green, } \\
\text { wide white } \\
\text { border, agar } \\
\text { turned yellow }\end{array}$ & 11 & $23 \cdot 1$ & $32 \cdot 6$ & 151 \\
\hline $\begin{array}{l}\text { Type A. Light or } \\
\text { medium green colo- } \\
\text { nies on Moyer's or } \\
\text { Czapek's agar and } \\
\text { white parts on nu- } \\
\text { trient agar }\end{array}$ & 80 & As above & 27 & $22 \cdot 9$ & $31 \cdot 5$ & 23 \\
\hline $\begin{array}{l}\text { Type B. Dark green } \\
\text { colonies or sectors on } \\
\text { Moyer's or Czapek's } \\
\text { agarand brown parts } \\
\text { on nutrient agar }\end{array}$ & 20 & $\begin{array}{l}\text { Dark green, } \\
\text { narrow white } \\
\text { border, agar } \\
\text { very slightly } \\
\text { yellow }\end{array}$ & 26 & $23 \cdot 2$ & $30 \cdot 2$ & 84 \\
\hline $\begin{array}{l}\text { Type C. Cream, white } \\
\text { or pale yellow colo- } \\
\text { nies or sectors on } \\
\text { Czapek's agar }\end{array}$ & $<1$ & Cream, raised & 3 & 13 & $25 \cdot 2$ & $\begin{array}{l}\text { Not } \\
\text { tested }\end{array}$ \\
\hline
\end{tabular}

* Obtained in assays of penicillin-producing capacity by the agar plug technique: the results given are in each case the average of the inhibition zones given by the plugs immediately adjacent to the colonies tested.

\section{Strain potency}

Plug assay of the plate cultures (see Chart) was used as an initial check on the potency of the strain before large-scale stages in production were reached, and also as a rough estimate of the value of new strains or of mutants of strains already in use.

Each Petri dish contained $20 \mathrm{ml}$. modified Czapek's agar ( $\mathrm{pH} \mathrm{7 \cdot 2)}$ and was centrally inoculated with a loop of spore suspension from the Moyer's agar slope. (Adjustment of the $\mathbf{p H}$ to $7 \cdot 2$ was important since the stability of penicillin decreases below pH 6.0, and it was found that plugs taken from $P$. chrysogenum X1612 cultures on Moyer's agar at pH 4.8 caused no inhibition zones on Staph. aureus plates.) After exactly 5 days' incubation at $25^{\circ}$, five $8 \mathrm{~mm}$. plugs were cut with a sterile cork-borer from the agar immediately adjacent to the mould colony. The plugs were transferred 
without inversion, by means of a spear-head needle, to an assay plate seeded with Staph. aureus, and placed at equidistant points about $25 \mathrm{~mm}$. from the centre. These assay plates were prepared and seeded as described later for the normal penicillin assay. After implantation the assay plates were incubated at $37^{\circ}$ for $16 \mathrm{hr}$. and the diameters of the clear circular inhibition zones around the plugs measured. As the size of the zones depends on the amount of penicillin diffusing from the plugs, a rough estimate could be made of the potency of the mould strain concerned.

The power of a surface colony to produce penicillin on an agar plate did not, however, always bear a strict relationship to the capacity of the strain for producing penicillin in submerged-liquid culture. For this reason, therefore, the plug assay was looked upon only as a convenient test for eliminating poor strains, and for routine checking of each strain prior to its use for large-scale work. Raper et al. (1944) used plugs cut from the mould colony itself, and from the agar in a radial series toward the edge of the plate. Plugs taken from the actual colonies of highly potent strains give zones over $40 \mathrm{~mm}$. in diameter and, in Petri dishes, these are distorted and are difficult to measure accurately. Furthermore, plugs equidistant from the same colony give variable results. We therefore considered it better to take five plugs of the latter type giving measurable zones of inhibition, and averaged the results to cover variation. The differences between individual values are presumably due to variable diffusion, or to variable penicillin production by different ares of the colony.

\section{Rye grain culture, sporulation, and spore viability}

The use of rye grain as a substrate for fungal growth is due to our colleague G. R. Rettew (private communication) although the procedure has been modified to suit our needs. Liquid sporulating medium $(25 \mathrm{ml}$.) was added to dry rye grain $(25 \mathrm{~g}$.$) in a plugged 500 \mathrm{ml}$. conical flask and autoclaved at $15 \mathrm{lb}$. pressure for $20 \mathrm{~min}$. Each such flask was inoculated with $1 \mathrm{ml}$. spore suspension from the Moyer's agar slope and well shaken. After 7 days' incubation at $25^{\circ}$ most of the rye grain surface was green with spores and the culture could be used immediately for making a spore suspension, or stored at $4^{\circ}$ for periods up to a fortnight. Spore suspensions were prepared by adding distilled water and shaking to release the spores. In early experiments a sample was taken for counting and the bulk used for inoculation without further treatment. Spore aggregation, however, rendered inaccurate both the counting and the subsequent measurement of the inoculum, and a crude filtration process was therefore included. A circular piece of muslin was hollowed into and wired over the mouth of a $500 \mathrm{ml}$. conical flask, the top of which was then covered with a wad of non-absorbent cotton-wool and greaseproof paper. After the assembly had been sterilized, the spore suspension was poured through the muslin under cover of the cotton-wool cap. Total counts were carried out with ten samples of the filtered material using a haemocytometer chamber of volume $0.005 \mathrm{~mm} .^{3}$. The final suspension normally contained $3-7 \times 10^{7}$ spores $/ \mathrm{ml}$, different times of incubation of the rye grain culture and a varying efficiency of filtration significantly affecting the count. One ml. lots of the suspension 
were transferred to soil tubes which were stored at $4^{\circ}$ for the purpose already described.

In order to establish the optimum conditions for penicillin production on a large scale it was necessary to be able to estimate the number of growing fungal colonies per unit volume of medium. As an essential stage of each production sequence, germination of a measured quantity of the spore suspension was carried out in a $10 \mathrm{l}$. aspirator bottle containing production medium (Gordon et al. 1947), and the problem was therefore to determine what proportion of the spores germinated under these conditions. This aspect appears to have received no attention from other workers.

Table 3. Viability of $\mathbf{P}$. chrysogenum spores

\begin{tabular}{|c|c|c|c|c|c|}
\hline Strain & $\begin{array}{l}\text { Culture used as source } \\
\text { of spore suspension }\end{array}$ & $\begin{array}{l}\text { Samples } \\
\text { counted }\end{array}$ & $\frac{\text { Spores germinated }}{\text { Spores inoculated }}$ & $\begin{array}{c}\text { Germi- } \\
\text { nation } \\
(\%)\end{array}$ & $\begin{array}{c}\text { Possible } \\
\text { range* }\end{array}$ \\
\hline X1612 & $\begin{array}{l}\text { 5-day Moyer slope } \\
\text { stored } 14 \text { days at } 4^{\circ}\end{array}$ & 50 & $1465 / 10,440$ & 14 & $3-100$ \\
\hline X 1612 & $\begin{array}{l}\text { 7-day rye grain stored } \\
2 \text { days at } 4^{\circ}\end{array}$ & 25 & $615 / 3748$ & 16 & $11-21$ \\
\hline X1612 & 7-day rye grain & 25 & $2658 / 6793$ & 39 & 23-79 \\
\hline X 1612 & 8-day rye grain & 10 & $1173 / 4603$ & 25 & $20-33$ \\
\hline Q176 & $\begin{array}{l}\text { 7-day rye grain stored } \\
3 \text { days at } 4^{\circ}\end{array}$ & 35 & $1775 / 3995$ & 45 & $19-72$ \\
\hline Q176 & 8-day rye grain & 25 & $6810 / 17,616$ & 39 & $18-55$ \\
\hline Q176 & 7-day rye grain & 25 & $1303 / 6374$ & 21 & 15-35 \\
\hline
\end{tabular}

* Range of percentage germination when calculated from the lowest and highest total spore counts rather than from the mean.

A portion of the muslin-filtered suspenion was diluted with four volumes of water, mixed and divided into two aliquots. One of these was used for determining the total count as above. According to the results obtained a further dilution of the second portion was made and an aliquot added to a known amount of modified Czapek's agar at $47^{\circ}$. After mixing well, the agar was distributed (10 ml. quantities) in Petri dishes which were then incubated at $25^{\circ}$. Colony counts were made on the second day and repeated on the third day, but not thereafter since sporing had started and secondary colonies were a possibility. The results were expressed as the percentage of the spores inoculated which germinated.

The conditions of the test were necessarily different from those in an aerated liquid production medium, but significant differences in germination were not expected since essential conditions were supplied in both cases. Results obtained with $P$. chrysogenum $\mathrm{X} 1612$ and Q176 are given in Table 3. The 'possible range' (see Table 3 ) was particularly wide in the first investigation in which no filtration of the spore suspension was included and spore aggregation resulted in very variable counts. The viability of the spores of these strains of $\boldsymbol{P}$. chrysogenum was much lower than anticipated, being in all cases less than $50 \%$, and this had to be taken into account when calculating the size of 
Microbiology of submerged culture of P. chrysogenum 181

inocula for production purposes. In view of these results, we feel that determination of spore count and spore viability of inocula is desirable for proper control of penicillin fermentations.

\section{Aspirator bottle culture and germination of spore inocula}

Germination of the spores used as inocula for small- and large-scale penicillin fermentations was accomplished in $10 \mathrm{l}$. Pyrex glass aspirators. The general assembly for this purpose was similar to that used for work on tyrothricin in these laboratories (Appleby, Knowles, McAllister, Pearson \& White, 1947). Normally, 7 l. of the medium (the same as that used in the subsequent production run) was made up in the aspirator assembly and autoclaved at $15 \mathrm{lb}$. for $30 \mathrm{~min}$. Spore suspension of known spore content was added through the inoculation inlet and the assembly incubated in a thermostatically-controlled room at 27.5 or $29.5^{\circ}$. Owing to the aeration, the temperature of medium was $2.5^{\circ}$ lower than that of the room. Aeration was normally at a rate of $1 \mathrm{l}$. air/l. medium/min., and no agitation other than that due to aeration was used. Initial frothing of the medium during incubation was decreased by adding, before sterilization, 1-3 ml. antifoam (2\% stearyl alcohol in lard oil). After 24-30 hr. excessive frothing generally occurred and 1-5 ml. lots of antifoam were again added through the inoculation inlet. The exit of air under pressure at this point minimized the possibility of contamination during this operation. Aspirator cultures for the germination of spore inocula for tank-scale fermentations were normally grown for $48 \mathrm{hr}$. and then used as described by Gordon et al. (1947).

Germinated cultures intended for the inoculation of further aspirator runs were grown for 2-4 days and then removed to the sterile room. The original level of the culture medium was restored by adding distilled water and, with knowledge of the initial spore number and of the percentage spore viability, the number of colonies per unit volume of the culture was estimated. The contents of the aspirator were well shaken and the required volumes removed through the sampling tube into sterile graduated flasks for inoculating the production aspirator runs. The apparatus and mode of operation for these was exactly the same as that used for inoculum germination. The results of such experiments are described by Gordon et al. (1947).

The purity of cultures was checked at each stage of the production sequence by plating on modified Czapek agar and on nutrient agar.

\section{The cup method assay}

\section{The assay of penicillin}

The procedure used was similar in essentials to that described by other workers (vide supra), but varied in certain details.

The cups used were of aluminium $(10 \mathrm{~mm} . \times 6 \pm 0 \cdot 1 \mathrm{~mm}$. internal diam.: $8 \mathrm{~mm}$. external diam.) with one end bevelled from the inner to the outer surface. Moisture condensation and consequent spreading of the test organism was prevented by using 
Petri dishes (10 cm. diam.) with porcelain Coor lids; these contained $21 \mathrm{ml}$. nutrient agar. A further quantity of the same agar was melted, cooled to $47^{\circ}$, and inoculated ( $1 \mathrm{ml}$. to $100 \mathrm{ml}$. medium) with a $16 \mathrm{hr}$. culture of Staph. aureus (N.C.T.C. 6571 a) in nutrient broth. Seeded agar $(4 \mathrm{ml}$.) was distributed evenly over the surface of each of the plates, which were then ready for use in the present method or in the plug assay method described earlier. Five cups were placed symmetrically on each plate; to ensure a good seal they were dropped on with forceps from a height of $c .3 \mathrm{~mm}$. immediately after the agar had set. Standard penicillin solution $(0 \cdot 2 \mathrm{ml} ., 1$ Oxford unit $/ \mathrm{ml}$.) was measured into cups 1 and 3 , and the same volume of the solution under test (adjusted to approximately the same penicillin content) to cups 2,4 and 5 . The plates were incubated for $16 \mathrm{hr}$. at $37^{\circ}$, and the diameters of the inhibition zones read to the nearest $0.5 \mathrm{~mm}$. The strength of the unknown was read from a standard

Table 4. Effect of various factors on the assay of penicillin by the 'cup assay' method

\begin{tabular}{|c|c|c|c|c|}
\hline Factor varied & Normally & $\begin{array}{l}\text { Experi- } \\
\text { mentally }\end{array}$ & $\begin{array}{c}\text { Average } \\
\text { change in } \\
\text { zone diameter } \\
(\% \text { of normal })\end{array}$ & $\begin{array}{c}\text { No. of } \\
\text { zones } \\
\text { measured }\end{array}$ \\
\hline $\begin{array}{l}\text { Age of Staph. aureus } \\
\text { inoculum (hr.) }\end{array}$ & 16 & $22 \cdot 5$ & $+4 \cdot 4$ & 156 \\
\hline $\begin{array}{l}\text { Temperature at which } \\
\text { agar inoculated }\left({ }^{\circ}\right)\end{array}$ & 47 & 56 & $+10 \cdot 5$ & 262 \\
\hline $\mathrm{pH}$ of agar & $6 \cdot 9$ & $6 \cdot 35$ & $+7 \cdot 3$ & 265 \\
\hline $\begin{array}{l}\text { Delay before incubating } \\
\text { plates after filling cups } \\
\text { (min.) }\end{array}$ & 30 & 60 & +4.5 & 105 \\
\hline Volume in cups (ml.) & 0.2 & $0 \cdot 1$ & $-11 \cdot 0$ & 79 \\
\hline
\end{tabular}

curve which had been obtained from experiments in which the five cups contained solutions of standard penicillin of concentrations $0.4,0.6,0.8,1.0$ and 1.3 Oxford units/ml. The standard curve was adjusted up or down the 'zone diameter' axis according to the plate variation indicated by the inhibition zones given on each plate by the two cups containing standard penicillin.

Solid standard penicillin (Provisional British Standard) was stored at $1^{\circ}$ and stock solutions (50 Oxford units/ml.) in ether-saturated water prepared every fortnight. These were further diluted as required with phosphate buffer $\mathrm{pH} 6 \cdot 0\left(\mathrm{~K}_{2} \mathrm{HPO}_{4}\right.$, $3.25 \mathrm{~g}$.; $\mathrm{KH}_{2} \mathrm{PO}_{4}, 10 \mathrm{~g}$.; water to $1325 \mathrm{ml}$.). Test solutions were passed through a bacterial filter to remove mycelium and diluted with the same buffer to $c$. 1 Oxford unit $/ \mathrm{ml}$. All solutions were kept cold until used.

Penicillin concentrations were calculated only from results obtained with test solutions containing from 0.9 to $1 \cdot 1$ Oxford units $/ \mathrm{ml}$. In order to avoid variation and possible contamination of the test organism (Staph. aureus) a routine check of the condition and purity of the test culture was made before each assay. Stock cultures on nutrient agar slopes were stored at $4^{\circ}$.

In early assays high average zone sizes and diffuse zone edges were sometimes encountered. As this tended to make the assays inaccurate, some investigation of the factors responsible was carried out. The use of Difco yeast extract in the assay medium produced sharp edges, while other yeast extracts tested gave diffuse edges. The effect of other factors on zone diameter is shown in Table 4; conditions which discouraged growth of the test organism 
caused an increase of zone size. The effect of varying several factors simultaneously was additive with the added disadvantage that there was a tendency towards indefinite diffuse zone edges.

The effect of varying the volume of solution placed in the cups is shown in Fig. 2. Other workers have specified only that the cups should be 'filled'. Increasing the volume added from 0.2 to $0.3 \mathrm{ml}$. gave an increase of $7.0 \%$ in the inhibition zone diameter. Errors of this order could therefore occur if the term 'filled' is laxly interpreted and we consider it essential to use a standard

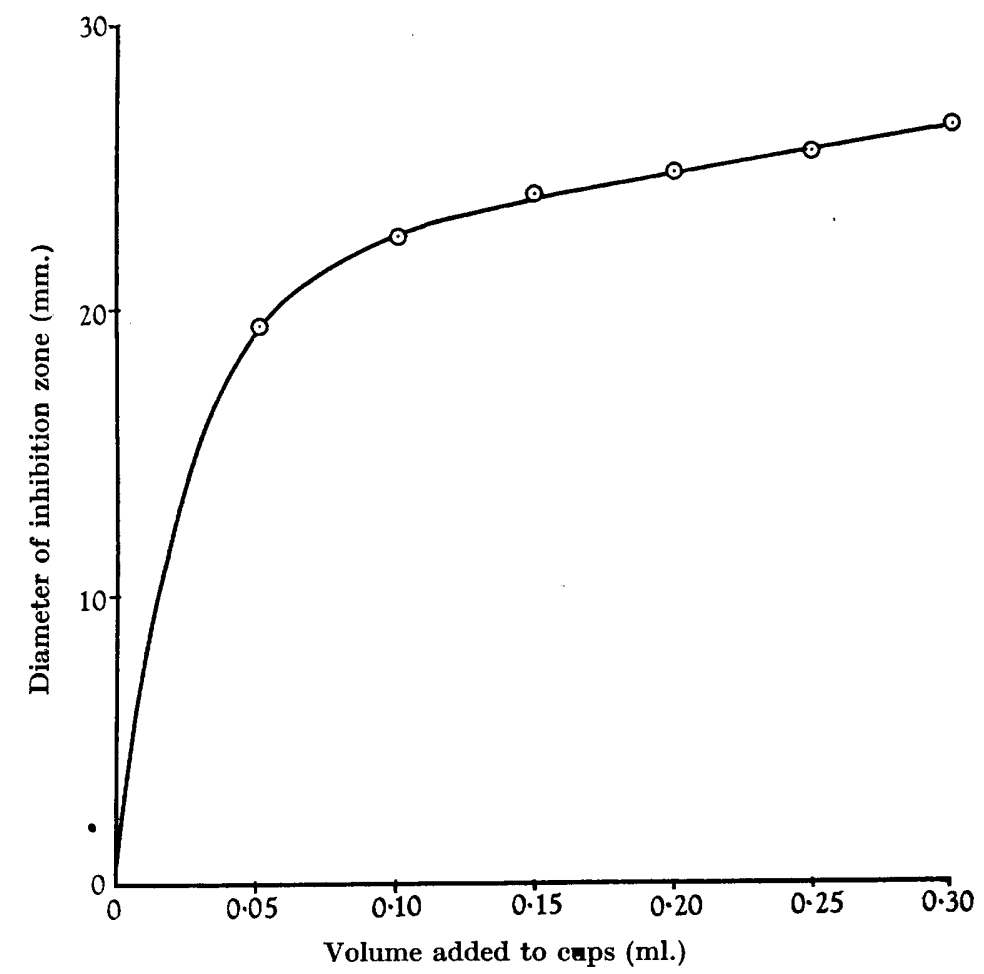

Fig. 2. Variation of diameter of inhibition zone with volume added to cups. Penicillin solution contained 1 Oxford unit/ml. (Provisional British Standard.)

volume. To obtain consistent results it is essential to adhere rigidly to the standard conditions of assay described, particularly as far as temperatures, $\mathrm{pH}$ values, and times are concerned. The overall error under these conditions is of the order of $5 \%$ only.

\section{The colorimetric broth assay method}

This method was devised in order to provide an alternative and more rapid method of assay which would give results in agreement with those of the cup assay. It was adapted from that developed for the assay of tyrothricin by Appleby, Knowles, Pearson \& White (1947). The method is based on the 
graded inhibition by increasing quantities of penicillin of the growth of Staph. aureus in nutrient broth, acid production being used as a measure of growth.

Standard penicillin was diluted to $\mathbf{0 \cdot 2}$ Oxford unit/ml. and the unknown to approximately the same concentration. The volumes shown in Table 5 were

Table 5. Colorimetric broth assay of an unknown penicillin solution

\begin{tabular}{|c|c|c|c|c|c|c|c|c|c|c|c|}
\hline & & & & & & Tube & & & & & \\
\hline & 1 & 2 & 3 & 4 & 5 & 6 & 7 & 8 & 9 & 10 & 11 \\
\hline $\begin{array}{l}\text { Standard or un- } \\
\text { known penicillin } \\
\text { solution (ml.)* }\end{array}$ & 0.0 & $0 \cdot 1$ & $0 \cdot 2$ & $0 \cdot 3$ & 0.4 & 0.5 & 0.6 & 0.7 & 0.8 & 0.9 & $1 \cdot 0$ \\
\hline $\begin{array}{l}\text { Penicillin present } \\
\text { in 'standard' } \\
\text { series (Oxford } \\
\text { units) }\end{array}$ & $0 \cdot 0$ & 0.02 & 0.04 & 0.06 & 0.08 & $0 \cdot 10$ & $0 \cdot 12$ & 0.14 & $0 \cdot 16$ & $0 \cdot 18$ & 0.20 \\
\hline $\begin{array}{l}\text { Growth: } \dagger \\
\text { 'Standard' series } \\
\text { 'Unknown' series }\end{array}$ & $\begin{array}{l}+ \\
+\end{array}$ & + & + & $\begin{array}{l}+ \\
\pm\end{array}$ & $\begin{array}{l} \pm \\
\pm\end{array}$ & $\frac{ \pm}{ \pm}$ & $\begin{array}{l} \pm \\
\pm\end{array}$ & $\frac{ \pm}{ \pm}$ & $\frac{ \pm}{ \pm}$ & \pm & - \\
\hline $\begin{array}{l}\text { Penicillin in } \\
\text { matching stand- } \\
\text { dard (Oxford } \\
\text { units) }\end{array}$ & . & . & . & . & . & $0 \cdot 12$ & . & $0 \cdot 16$ & . & $0 \cdot 20$ & . \\
\hline $\begin{array}{l}\text { Penicillin in un- } \\
\text { diluted unknown } \\
\text { (Oxford units } / \mathrm{ml} \text {.) }\end{array}$ & . & . & . & . & . & 240 & . & 229 & . & 222 & • \\
\hline
\end{tabular}

* Standard, 0.2 Oxford unit/ml.; unknown, 1/1000 dilution of solution under test.

++ signifies indicator turns yellow, and - that it remains purple; \pm represents intermediate changes.

Table 6. Comparison of two methods for the assay of penicillin

\begin{tabular}{ccc}
\multicolumn{2}{c}{$\begin{array}{c}\text { Penicillin found } \\
\text { (Oxford units/ml.) }\end{array}$} \\
Sample & $\overbrace{\begin{array}{l}\text { Colorimetric } \\
\text { broth assay }\end{array}}^{\text {Cup assay }}$ \\
1 & 40 & 40 \\
2 & 142 & 141 \\
3 & 143 & - \\
& 225 & 218
\end{tabular}

then measured into two series of $3 \times \frac{1}{2}$ in. tubes (one series for the standard and the other for the unknown). Water was added to each tube to bring the volume to $1 \mathrm{ml}$. Papain heart digest broth (Appleby, Knowles, Pearson \& White, 1947) containing $1 \%(\mathrm{w} / \mathrm{v})$ glucose and $3 \%$ bromcresol-purple indicator solution (British Drug Houses Ltd.) was mixed with one-twentieth of its volume of a $16 \mathrm{hr}$. broth culture of Staph. aureus, and $1 \mathrm{ml}$. mixture added to each assay tube. The latter were then inverted once to mix, and incubated in a water bath at $37^{\circ}$ for $4 \mathrm{hr}$. The result was obtained by comparing tubes of the two series in which inhibition of growth was partial, i.e. those in which the indicator showed an intermediate colour change. Tubes from the unknown and 
standard series were matched visually, and the results calculated from the average given by three or four matching tubes (Table 5). The overall error of the method was judged to be $c .15 \%$. Table 6 shows that the results were in close agreement with those obtained by the cup assay method; turbidimetric methods, on the other hand, usually tend to give higher values. Aseptic precautions were taken throughout, but this is possibly not essential in view of the short incubation period.

Using this method, the penicillin content of a production sample can be estimated within $5 \mathrm{hr}$, and the course of penicillin production can be followed more closely than would be otherwise possible.

The authors wish to express their gratitude to Mr A. J. C. Gormley, Managing Director of John Wyeth and Bro. Ltd., for permission to publish the above results.

\section{REFERENCES}

Abraham, E. P., Chain, E., Fletcher, C. M., Gardner, D. A., Heatley, N. G., Jennings, M. A. \& Florey, H. W. (1941). Further observations on penicillin. Lancet, ii, 177.

Appleby, J. C., Knowles, E., McAluister, R. C. A., Pearson, J. \& White, T. (1947). The production of tyrothricin by submerged culture of Bacillus brevis in synthetic media. J. gen. Microbiol. $1,145$.

Appleby, J. C., Knowles, E., Pearson, J. \& White, T. (1947). A preliminary study of the formation, assay and stability of tyrothricin. J. gen. Microbiol. 1, 137.

Beadle, G. W., Mitchell, H. K. \& Bonner, D. (1945). Improvements in the cylinder-plate method for penicillin assay. J. Bact. 49, 101.

Clutrenbuck, P. W., Lovell, R. \& Raistrick, H. (1932). Studies in the biochemistry of micro-organisms. XXVI. The formation from glucose by members of the Penicillium chrysogenum series of a pigment, an alkali-soluble protein and penicillin-the antibacterial substance of Fleming. Biochem. J. 26, 1907.

Fueming, A. (1929). On the antibacterial action of cultures of a Penicillium, with special reference to their use in the isolation of B. influenzae. Brit. J. exp. Path. $10,226$.

Foster, J. W. \& Woodruff, H. B. (1943). Microbiological aspects of penicillin. I. Methods of assay. J. Bact. 46, 187 .

Foster, J. W. \& Woodruff, H. B. (1944). Microbiological aspects of penicillin. VI. Procedure for the cup assay for penicillin. J. Bact. 47, 43.

Foster, J. W., Woodruff, H. B. \& McDaniel, L. E. (1943). Microbiological aspects of penicillin. III. Production of penicillin in surface cultures of Penicillium notatum. J. Bact. 46, 421.

Gordon, J. J., Grenfell, E., Knowles, E., Legge, B. J., McAllister, R. C. A. \& WhITE, T. (1947). Methods of penicillin production in submerged culture on a pilot-plant scale. J. gen. Microbiol. 1, 187.

Hanson, H. J., Myers, W. G., Stahly, G. L. \& Birkeland, J. M. (1946). Variation in Penicillium notatum induced by the bombardment of spores with neutrons. J. Bact. 51, 9.

Knudsen, L. F. \& Randall, W. A. (1945). Penicillin assay and its control chart analysis. J. Bact. 50, 187.

Koffler, H., Emerson, A. L., Perlman, D. \& Burris, R. M. (1945). Chemical changes in submerged penicillin fermentations. J. Bact. $50,517$. 
Moyer, A. J. \& Cogmill, R. D. (1946a). Penicillin. VIII. Production of penicillin in surface cultures. $J$. Bact. 51, 57 .

Moyer, A. J. \& Coghin, R. D. $(1946 b)$. Penicillin. IX. The laboratory scale production of penicillin in submerged cultures by Penicillium notatum Westling (NRRL 832). J. Bact. 51, 79.

Rahn, O. (1945). Physical methods of sterilization of micro-organisms. Bact. Rev. $9,1$.

Raper, K. B., Alexander, D. F. \& Coghill, R. D. (1944). Penicillin. II. Natural variation and penicillin production in Penicillium notatum and allied species. J. Bact. 48, 639.

Raper, K. B. \& Fennel, D. I. (1946). The production of penicillin $X$ in submerged culture. J. Bact. 51, 761.

Reyniers, J. A. (1943). Micrurgical and Germ-free Methods. Baltimore: Thomas.

Schmidt, W. M. \& Moyer, A. J. (1944). Penicillin. I. Methods of assay. J. Bact. $47,199$.

Thom, C. \& Raper, K. B. (1945). A Manual of the Aspergilli. Baltimore: Williams and Wilkins.

(Received 28 October 1946) 